\title{
Development of Andesite Utilization in Gunung Ragas, Clering, Jepara, in the Industrial Sector Based on Petrological and Geochemical Data Analysis
}

\author{
Dian Agus Widiarso*, Roynaldo Lumbanbatu, Vergania Nurlita Putri, Jenian Marin \\ Department of Geological Engineering, Diponegoro University, Semarang, Indonesia
}

\begin{abstract}
The research area was the exposed extruded igneous lava rock in Clering which became the mining location of PT Semarang Mineral Pembangunan in Clering, Donorejo, Jepara with an area of \pm 11 ha. This study aims to identify and determine the composition of andesite minerals by macroscopic and microscopic, the main oxide compound data, the use of andesite in industrial sector. The lithology consisted of andesite lava textured, plagioclase, leucite, clinopyroxene, sanidine as phenocryst and ground mass in the form of microlithic andesite lava as a trachytic texture. The hardness of lithology tends to be more moderate, it is considered unsuitable for building foundations. Andesite and tuff in the study area are currently being mined to be used as raw material for glass because of high silica content. In the industrial sector, the feldspar minerals for flux glass, and ceramic raw materials with standard of PT Semarang Mineral Pembangunan and SNI ISO 14703: 2011, 1147-1984 and SNI ISO 12543: 2011. The lithology tuff can be utilized in the manufacturing of ceramics due to high silica and felspar content. The lithology andesite can be utilized as rocks flour in the manufacturing of fertilizer due to high natrium, potassium, and magnesium content.
\end{abstract}

\section{Introduction}

The research location is located in Clering, Jepara, Central Java, Indonesia (Fig. 1). It was observed in mine production field of PT Semarang Mineral Pembangunan which is located about $40 \mathrm{~km}$ ( \pm 60 minutes) to the west of Pati, Central Java and about $112 \mathrm{Km}( \pm 180$ minutes) to the north of Semarang City. Physiographically, the research location is included in Quarterly Volcanic Region [1] characterized by volcanic morphology such as Genuk Mount cone in the west [2]. The results of volcanic activity (product of volcanism) by Genuk Mount causes either intrusive rock or extrusive rock to form in some places such as shown in Clering Village, Jepara. Thus, Clering Village has the potential of mining excavation type "C" especially andesite and tuff.

\footnotetext{
* Corresponding author: dianagusgeo@gmail.com
} 

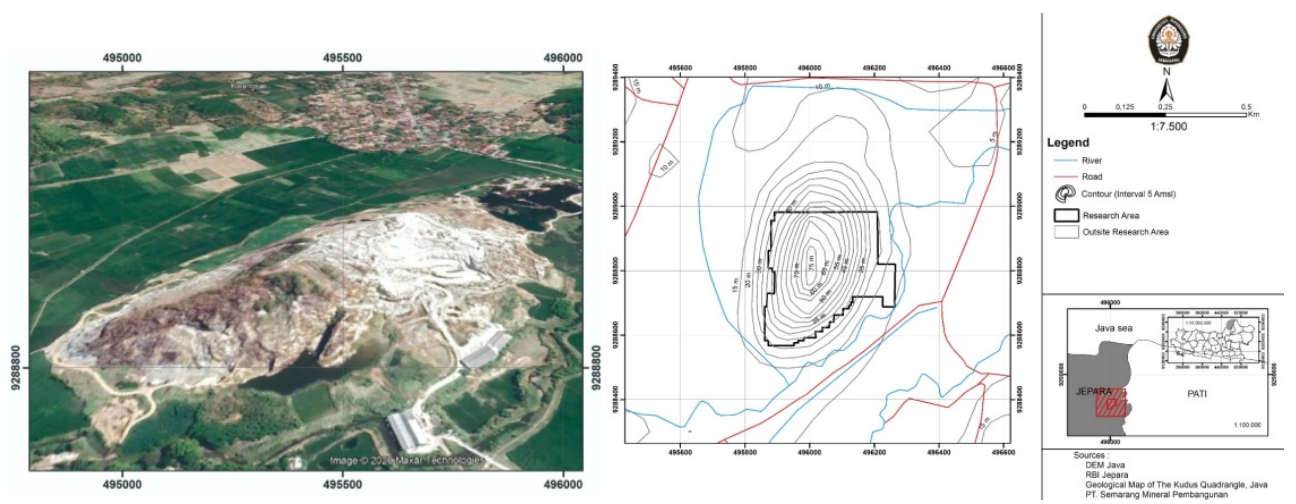

Fig. 1. The research location map is located in the mine production field of PT Semarang Mineral Pembangunan, Clering, Jepara, Central Java, Indonesia.

The andesite in Ragas Mount located in production field of PT Semarang Mineral Pembangunan in Clering Jepara (Fig. 1) is unique in the form of physical properties of rock where this andesite has the different hardness than another type of andesite that commonly found. There is also another type of igneous rock which is tuff located above the andesite.

Hence, this research aims to identify andesite characteristics that mined with geological data such as rock observation and rock geochemistry to determine the exact of lithology, therefore it can be used as an interpretation in studying volcanism or magmatism in the research area.

\section{Regional Geological Conditions}

The research location has an area of 11.7 hectares. It is located in Clering Village, north part of Javanese shoreline. Physiographically, the research location is included in Quarterly Volcanic Region [1] characterized by volcanic morphology such as Genuk Mount cone in the west [2].

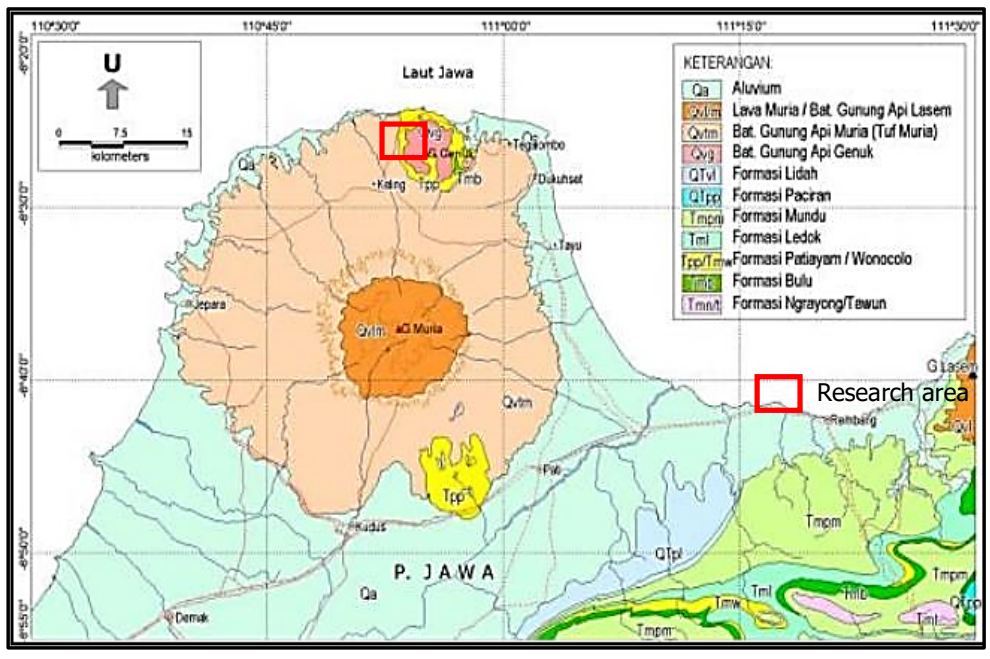

Fig. 2. Geological Map of research area located in Kudus, Central Java [2] 
According to Kudus Geological Map which was made [2], stratigraphical condition in Clering can be divided into several formations formed in Tertiary until Quartenary (Fig. 2).

1. Patiayam Formation formed in Pliosen (TPP), is composed by interbedded sandstonetuff and tuff-conglomerate.

2. Quartenary Vulcanic Genuk Formation (QVG) formed in Early Pleistocene - Late Pleistocene, is consisted of vulcanic rock such as lava, vulcanic breccia, and tuff.

3. Alluvium (Qa) formed in Holocene is composed by gravel, sand, clay, silt, and volcanic material.

The research area is located in Java Island which regionally is a part of back arc from the result of convergent interactions between the Indian-Australian Ocean Plate and the Eurasian Plate. The research location is formed in Early Pleistocene - Late Pleistocene [2].

Semenanjung Muria Complex is located in Jepara, Kudus, and Pati of Central Java. This Complex was associated with passive Muria Mount in vulcanic arc, inactive fault Central Java in Rembang. This Complex was consisted of inactive Muria Mount, and two smaller mount (flank eruption) named Genuk Mount and Patiayam Mount. Based on the past researches, Muria Mount Complex vulcanostratigraphy was consisted of three regions that chronologically started from Patiayam Mount in the southern, followed by Genuk Mount in the northern, and the last is Muria Mount in the central. Each of vulcanic area showed some creaters, shown some eruption points that moving from one point to another point. This eruption created flow, fall, and pyroclastic deposit, dome, lahar deposit, also fluvial deposit. The succession of vulcanic product and geochronologic based on age datas from NEWJEC (New Japanese Engineering Consultant) (1996) and NTT (National Technical Team) (2000).

Secondary data of geochemistry in Muria Mount (Newjec, 1996 and NTT, 2000) (Table 1) showed the magma series are high calc-alkaline to shoshonitic series, with alkaline rocks that composed by $\mathrm{SiO}_{2}$ in range $45-55$ w.t. $\%, \mathrm{~K}_{2} \mathrm{O}+\mathrm{Na}_{2} \mathrm{O}$ 6-11 w.t.\%, and showed that tectonical setting of the research area is MORB tectonical setting (Mid Oceanic Ridge Basalt) based on the rare element ratio $\mathrm{Zr} / \mathrm{Nb}$ vs ${ }^{86} \mathrm{Sr} /{ }^{87} \mathrm{Sr}$.

Table 1. Geochemical Data of Muria Mount and Genuk Mount (New Japanese Engineering Consultand, 1996 and National Technical Team, 2000)

\begin{tabular}{lcrrrrrrrrrr}
\hline & $\mathrm{SiO}_{2}$ & $\mathrm{TiO}_{2}$ & $\mathrm{Al}_{2} \mathrm{O}_{3}$ & $\mathbf{F e}_{2} \mathbf{O}_{3}$ & $\mathbf{F e O}$ & $\mathbf{M n O}$ & $\mathbf{M g O}$ & $\mathbf{C a O}$ & $\mathbf{N a}_{2} \mathbf{O}$ & $\mathbf{K}_{2} \mathbf{O}$ & $\mathbf{P}_{2} \mathbf{O}_{s}$ \\
\hline GG-1 & 53,07 & 0,82 & 17,96 & 1,85 & 6,17 & 0,19 & 3,04 & 7,79 & 3,6 & 5,05 & 0,64 \\
\hline GG-2 & 54,21 & 0,63 & 20,33 & 1,36 & 4,54 & 0,18 & 1,59 & 5,75 & 4,64 & 6,59 & 0,32 \\
\hline GG-3 & 47,84 & 0,79 & 14,98 & 2,22 & 7,39 & 0,17 & 5,94 & 13,02 & 2,12 & 3,87 & 0,85 \\
\hline GG-4 & 47,08 & 1,33 & 10,49 & 2,25 & 7,5 & 0,11 & 3,58 & 13,52 & 1,96 & 4,06 & 0,73 \\
\hline GG-5 & 49,38 & 0,96 & 16,65 & 2,18 & 7,26 & 0,2 & 4,44 & 10,29 & 2,69 & 5,24 & 0,93 \\
\hline GG-6 & 47,74 & 0,99 & 15,75 & 2,22 & 7,39 & 0,18 & 5,05 & 11,9 & 3,12 & 4,86 & 1,03 \\
\hline GM-1 & 48,61 & 1,15 & 21,25 & 1,84 & 6,14 & 0,21 & 3,69 & 7,24 & 4,16 & 4,46 & 0,58 \\
\hline GM-2 & 52,48 & 0,86 & 16,69 & 1,96 & 6,53 & 0,17 & 3,54 & 8,98 & 3,23 & 4,93 & 0,82 \\
\hline GM-3 & 56,55 & 0,32 & 23,74 & 0,69 & 2,29 & 0,15 & 0,47 & 2,91 & 4,16 & 8,7 & 0,09 \\
\hline GM-4 & 53,35 & 0,49 & 22,01 & 1,13 & 3,78 & 0,2 & 1 & 5,07 & 6,38 & 6,48 & 0,22 \\
\hline GM-5 & 51,33 & 0,85 & 19,18 & 1,65 & 5,51 & 0,12 & 2,86 & 8,22 & 3,71 & 6,15 & 0,37 \\
\hline GM-6 & 49,49 & 0,56 & 16,52 & 1,76 & 5,87 & 0,15 & 6,03 & 11,31 & 3,42 & 3,74 & 0,49 \\
\hline
\end{tabular}




\section{Research Methodology}

There are systematic methodology stages (Fig. 3) consist of literature review, collecting data, and composing data. Primary datas used in this research include the coordinates of the study area through coordinates mobile GPS and rock samples (3 samples). The secondary datas of the study are using the topographic map data of the research area, the geological map of the research area, DEM (Digital Elevation Model), the administrative map of the research area, and the legal area boundary of PT Semarang Mineral Pembangunan.

Sequently, data processing consists of : identification of rocks including mineral composition in megascopic, classifying rocks using the classification of Russel B. Travis (1955), incising the rocks to determine the mineral composition of rock compilers, observing and identifying petrographically including rock texture (general and special rocks), mineral composition and classifying the rocks by using IUGS classification [4], inputting the location coordinates and the legal area boundary (IUP shapefile) and map layouting using ArcGIS 10.3 software, conducting X-Ray Fluorenscence analysis (XRF) to determine the chemical composition of the these rocks and their chemical elements, make an interpretation model of the formation of igenous rock in the research location with CorelDraw graphic design software, and composing the report.
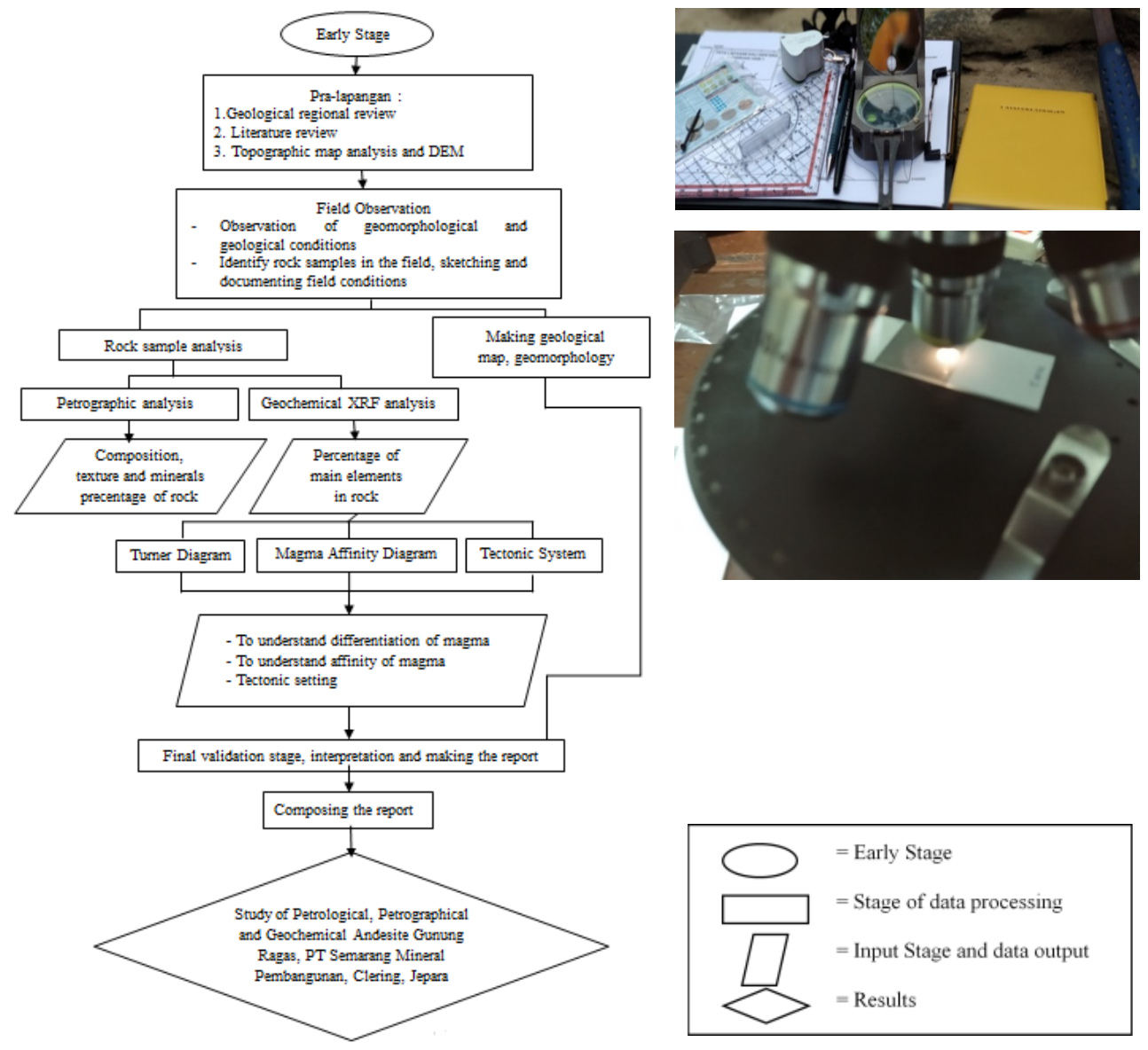
Fig. 3. Research flow chart obtained in the research

\section{Result and Discussion}

\subsection{Field Observation and Petrological Analysis}

From the field observation, it is known that the research area in PT Semarang Mineral Pembangunan, Jepara, is located in the vulcanic landform [1] (Fig. 4), characterized by the morphology of Genuk Mountain in the west [2]. The research area is located in Batuan Gunungapi Genuk Formation (QVG), which is formed in Early Pleistocene - Late Pleistocene. The formation is composed of lava, vulcanic breccia, tuff [2]. The appearance of outcrop consists of lithology andesite and tuff. The land use is currently mining areas close to settlement areas.

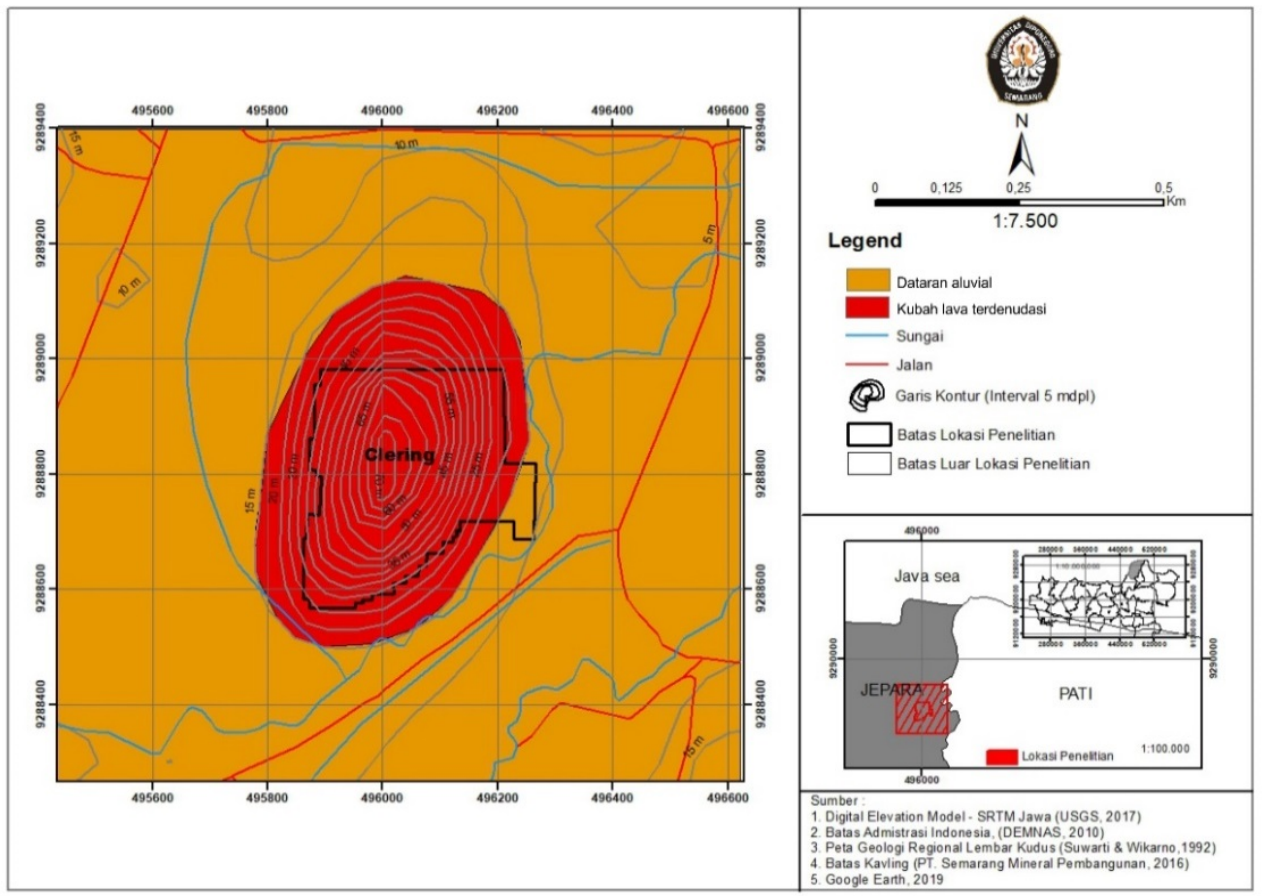

Fig. 4. Geomorphological map of the study area showing lava dome morphology

The lithologic map shows that study area is consisted of andesite and alluvium (Fig. 5). In general, andesite in study area is black to gray in color, with massive structure and low weathering levels. The igneous rock texture in andesite by hand specimens includes the degree of hypocrystalline crystallinity, inequigranular granularity, size of porphyritic crystals, and subhedral crystal shape (Fig. 6).

The tuffs are generally white to brownish yellow, with massive structure and weathering levels tend to be low to medium. The igneous rock texture on the tuff by hand specimens includes the size of the afanitic crystals, good sorting, closed grain-packaging, rounded grain shape, and has no cleavage.

There are fractures in the outcrops of both shear fractures and joint fractures. Unique features found in the field are the appearance of andesite rocks beneath tuff rocks. In some 


\section{ICENIS 2020}

places on boundary of andesite an tuff, the two lithologies appear to be mixed, wherein andesites are partially inserted in tuffs with an average size of $10 \mathrm{~cm} \times 10 \mathrm{~cm}$ (Fig. 6).

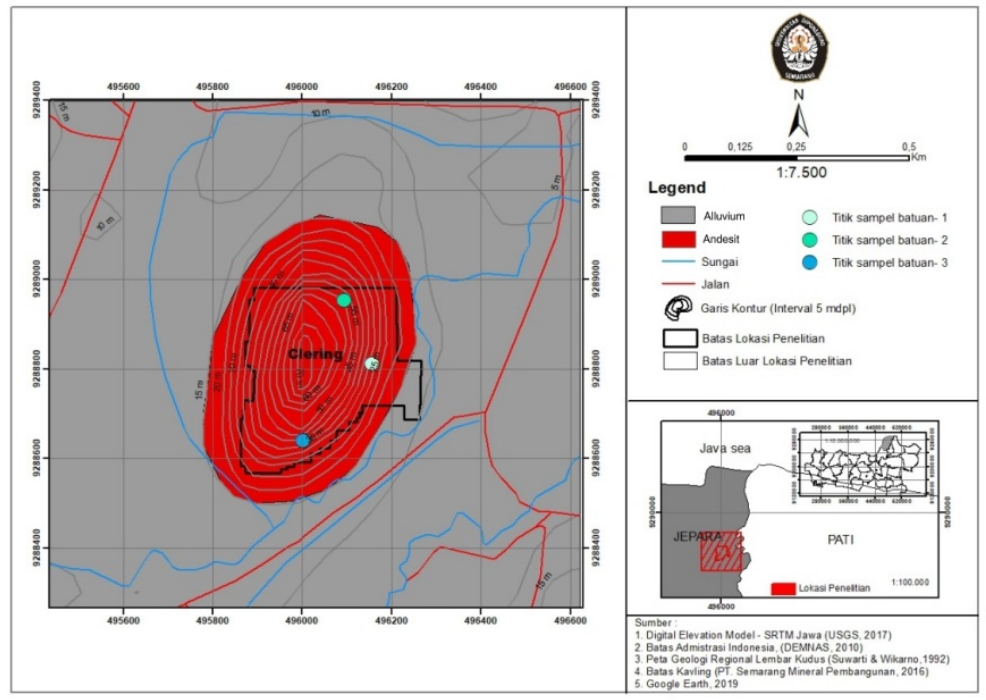

Fig. 5. Lithologic map of the study area showing andesite lithology.

In the andesite-b section (Fig. 6) there is a fracture that triggers a weak zone so that rocks interact exogenically faster. The weathering process is certainly caused by several media, generally in the form of water flow, humidity, climate and weather, and the weathering process itself can be caused chemically and mechanically, for mechanical weathering in these rocks is more controlled by cracks in rocks while chemically is controlled by elements / chemical compounds in rocks. 


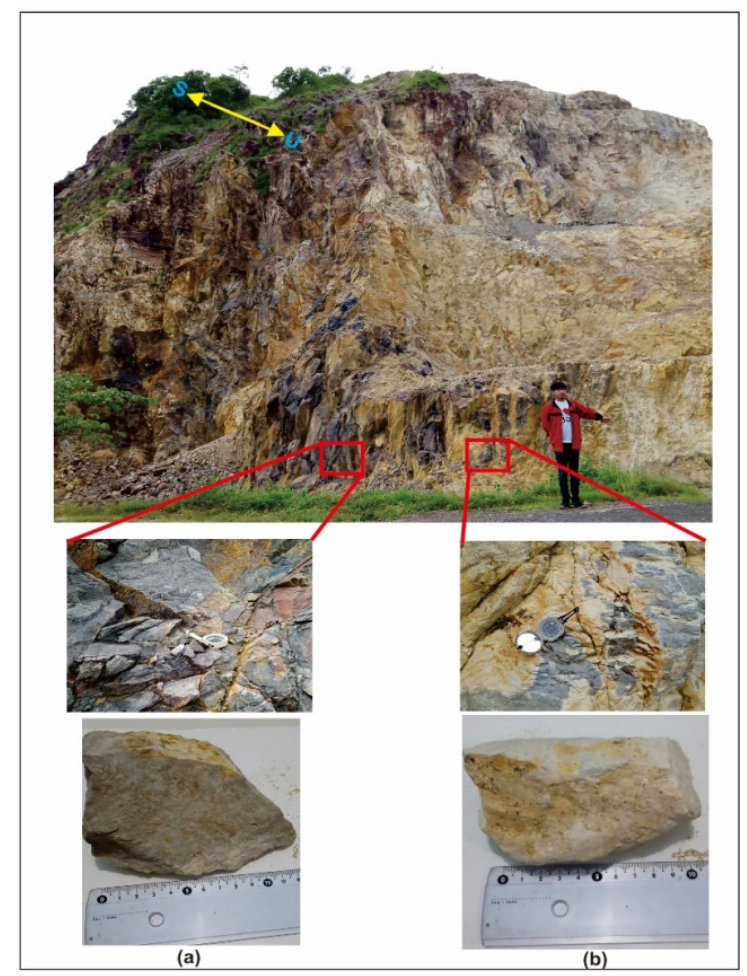

Fig. 6. Andesite lithology (a) and (b) of research area.

\subsection{Petrographic Analysis}

The petrographic analysis of Clering andesite and tuff samples (Fig. 7) resulted in the composition of mineral content and rock names determined based on the classification of Russel B. Travis (1955) [3] and IUGS-Streickeinsen (1967) [4] for non-fragmental igneous rocks such as andesite, and Pettijohn (1975) [5] for fragmental rocks such as tuff.

Based on the results of petrographic analysis (Fig. 7), andesites were identified as having a black to grayish texture, hypocrystalline degree of crystallinity, porphyritic inequigranular granularity, subhedral crystal shape, porphiroafanitic crystal size $(0.5-2$ $\mathrm{mm})$, massive and vesicular structures. Porphyritic phenocryms consist of quartz minerals $(20 \%)$, orthoclasts with twinning angles of 45 (20\%), clinopyroxen (5\%), and opaque minerals $(10 \%)$. Afanitic ground mass consists of plagioclase minerals (20\%) with a twin angle of 30 which is known as Labradorite An52, quartz (10\%), glass or vitric (5\%), and opaque minerals (5\%). Specific textures that appear in thin section of andesite (Fig. 7) are porphyritic texture, polyclitic, sieve texture, and there are also trachytic textures in several parts of the thin section. Based on the composition and texture of andesite, it is known that the identified name of andesite lava is Porphyry latite quartz[3] and Quartz latite [4]. 


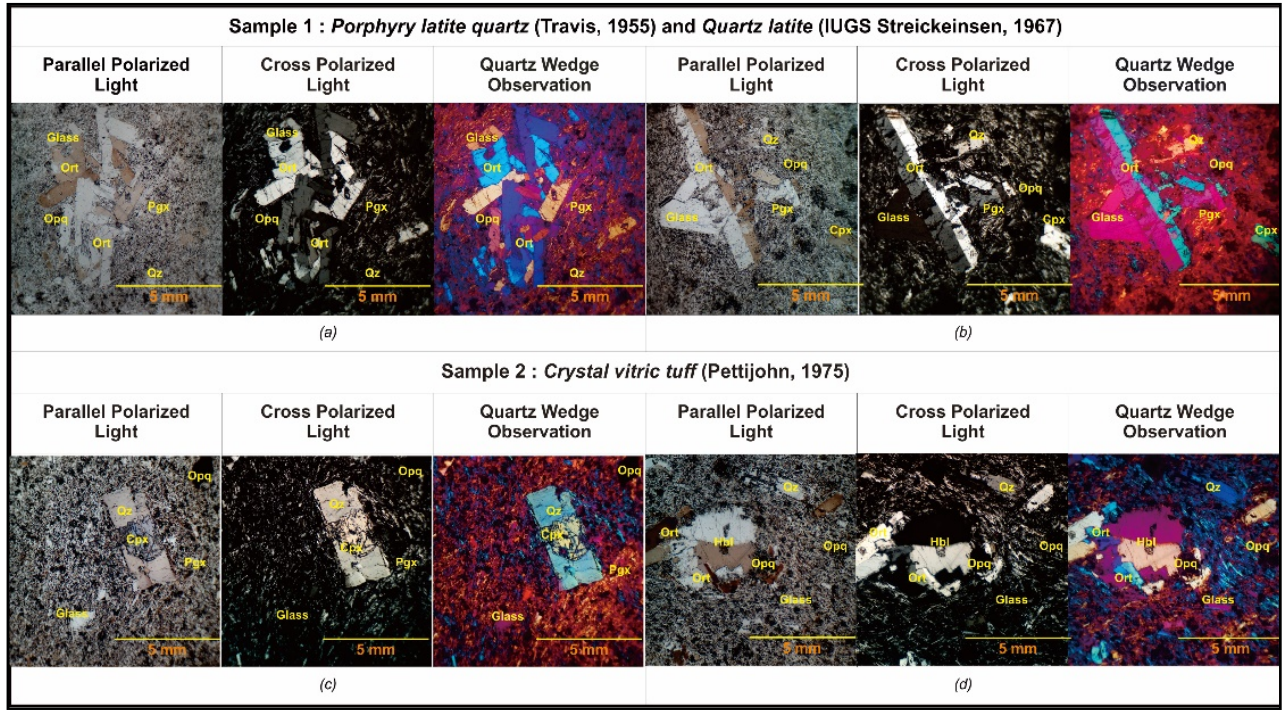

Fig. 7. Petrographic analysis of sample 1 (andesite lava) and sample 2 (tuff). Both samples have the same specific texture, namely trachitic texture and porphyritic texture.

In andesite thin section observation (Fig. 7), the presence of porphyry texture with the characteristics of phenocrystalline minerals embedded in fine-sized ground mass crystals indicates crystallization of magma under two different conditions. Phenocrises will tend to form first when the magma is still cooling relatively slowly, then when the magma moves up, the ambient temperature makes the magma cool faster so that the crystals will be relatively smaller in size than the crystals that are formed first. Polyclitic texture is found in all rock incisions, shown by phenocris plagioclase and surrounded by randomly crystallized plagioclase microlites. This happens because phenocrysts are formed first, followed by plagioclase microlites, this condition generally characterizes the shallow freezing region. Sieve texture, which is phenocris plagioclase which experiences melt and crystallizes minerals in that part. This texture is formed due to the process of mixing magma which melts the plagioclase that was previously formed. While the trachitic texture is caused by the lava flow which causes the appearance of flow lines in the form of alignment of minerals which are generally in the form of feldspar microlites. Based on the data obtained both petrologically and petrographically, in the study area, the identified andesite is a product of lava formed in the extrusive zone.

Based on the results of petrographic analysis (Fig. 7), tuffs were identified as having porphyritic inequigranular granularity, degree of hypocrystalline crystallinity, porphyroaphanitic crystal size $(0.5-2 \mathrm{~mm})$ and massive structures. Porphyritic phenocryms consist of quartz minerals, orthoclasts, clinopyroxen, hornblenda, opaque minerals and minerals. The basic mass of afanitic consists of plagioclase minerals with a twin angle of 25. which is known to be an Andesine An48 type of plagioclase, quartz, gelas, and opaque minerals. So that it can be identified that the composition of these rock includes of vitric $(25 \%)$ and crystal (75\%). Special textures that appear in thin section of tuff are porphyritic, hyalophylitic, intersertal, and trachitic. Based on the composition and texture of tuff, it is known that the identified name of tuff is Crystal Vitric Tuff [5].

In tuff thin section observation (Fig. 7), the presence of porphyry texture with the characteristics of phenocrystalline minerals embedded in fine-sized ground mass crystals indicates crystallization of magma under two different conditions. Hyalopilitic texture is a pyroclastic rock texture where the feldspar is surrounded by a basic mass of volcanic glass. 
Intersertal texture is igneous rock texture shown by the intersertal arrangement between plagioclase crystals; plagioclase microlites that are between / in the ground mass of the interstitial glass. While the trachitic texture is caused by the lava flow which causes the appearance of flow lines in form of alignment of minerals which are generally in the form of feldspar microlites. Based on the data obtained both petrologically and petrographically, in the study area, andesite is a product of lava formed in the extrusive zone.

\subsection{Geochemical Analysis}

The method used in identifying chemical elements / compounds in rocks is the XRF method (X-Ray Fluorescent) conducted at the Laboratory of PT Geoservices - GeoAssay Laboratory on 2 samples of Mount Ragas lava which chemical composition is identified. From the results of this analysis, the percentage of oxide chemical elements (Table 2) such as $\mathrm{SiO}_{2}, \mathrm{TiO}_{2} . \mathrm{Al}_{2} \mathrm{O}_{3}, \mathrm{Fe}_{2} \mathrm{O}_{3}, \mathrm{MnO}_{3}, \mathrm{CaO}, \mathrm{BaO}, \mathrm{Cr}_{2} \mathrm{O}_{3}, \mathrm{SO}_{3}, \mathrm{MgO}, \mathrm{Na}_{2} \mathrm{O}, \mathrm{SrO}_{2}, \mathrm{~K}_{2} \mathrm{O}$ and $\mathrm{P}_{2} \mathrm{O}_{s}$. Then the element values are processed using the "CIPW Norm Calculator". Based on rock chemical data, characteristics of rock type, original magma, and magma depth can be determined as follows.

Table 2. The percentage of oxide chemical elements

\begin{tabular}{|c|c|c|}
\hline Oxide Chemical Data & RGS-1 & RGS-2 \\
\hline $\mathrm{Al}_{2} \mathrm{O}_{3}$ & 20,94 & 21,09 \\
\hline MgO & 0,05 & 0,06 \\
\hline $\mathrm{Fe}_{2} \mathrm{O}_{3}$ & 1,99 & 1,35 \\
\hline $\mathrm{CaO}$ & 0,54 & 0,42 \\
\hline $\mathrm{Na}_{2} \mathrm{O}$ & 5,15 & 5,23 \\
\hline $\mathrm{K}_{2} \mathrm{O}$ & 6,37 & 6,51 \\
\hline $\mathrm{SiO}_{2}$ & 62,34 & 61,36 \\
\hline MnO & 0,09 & 0,04 \\
\hline SO3 & 1,17 & 1,25 \\
\hline SrO & 0,01 & 0,01 \\
\hline $\mathrm{BaO}$ & 0,01 & 0,01 \\
\hline $\mathbf{P}_{2} \mathbf{O}_{s}$ & 0,03 & 0,03 \\
\hline $\mathrm{Cr}_{2} \mathrm{O}_{3}$ & 0,03 & 0,01 \\
\hline $\mathrm{TiO}$ & 0,11 & 0,13 \\
\hline
\end{tabular}

\subsection{Geotechnical of Feldspar Andesite of Mount Ragas in Industrial Sector}

Andesite which is an extrusive igneous rock formed from the main minerals making up the rock by the crystallization process of magma at each different temperature. The composition of andesite minerals that are often found are feldpar minerals. Feldspar ( $\mathrm{KAlSi}_{3}$ - $\mathrm{NaAlSiO}_{3}-\mathrm{CaAl}_{2} \mathrm{Si}_{2} \mathrm{O}_{8}-\mathrm{BaAl}_{2} \mathrm{Si}_{2} \mathrm{O}_{8}$ ) is a group of minerals consisting of Potassium (K), Sodium $(\mathrm{Na})$ and calcium alumina silicate, and including tectosilicate minerals. Feldspar is composed of chemical and mineralogical elements divided into two, namely:

a) Alkali Feldpar (orthoclast, microline, sanidine)

b) Plagioclase (anortite, bitownite, labradorite, andesine, oligoclast, albit)

Feldspar belongs to industrial minerals or minerals from non-metallic minerals. Feldspar and its associated minerals after being processed can be used for gerindra and other industrial needs. Feldspar is generally used to eliminate or reduce levels of impurities minerals such as iron minerals, biotite, quartz, mica. For example, to manufacture good quality porcelain with a maximum $\mathrm{Fe}_{2} \mathrm{O}_{3}$ content of $0.5 \%$. 
Feldspar is also utilized as a raw material for the ceramics industry if the $\mathrm{Na} 2 \mathrm{O}$ and K2O levels refer to the standards made by the Indonesian National Standard (SNI), SNI No. 1145-1984, while the utilization in other industries, in the form of glass and glass industry, also refers to standards made by SNI ISO 12543: 2011. The chemical standard values in wt.\% For the glass and glass industry are as follows:

a) Glass Industry (SNI ISO 12543-1: 2011)
a. $\mathrm{SiO} 2$ between $68-69.8 \%$
b. $2 . \mathrm{Al} 2 \mathrm{O} 3>17 \%$
c. $\mathrm{K} 2 \mathrm{O}+\mathrm{Na} 2 \mathrm{O}>11 \%$
d. $\mathrm{Fe} 2 \mathrm{O} 30.1 \%-0.2 \%$

b) Glass industry (SNI ISO 12543-1: 2011)
a. $\mathrm{SiO} 2 \min 65.7 \%$
b. $\mathrm{Al} 2 \mathrm{O} 3>18 \%$
c. $\mathrm{Fe} 2 \mathrm{O} 3<0.8 \%$
d. $\mathrm{K} 2 \mathrm{O}>10 \%$

Andesite which is physically quite hard, can be used as an excavation material as a building foundation material, road hardener material and a raw material for making ceramics, glass and glass, where the mineral content of the andesite is the mineral feldspar.

In general conditions found at the mine site physically andesite does not have a hard enough hard dominant softer than andesite that is usually found so that it refers to it, then this andesite cannot be used as material for mining industry in the field of use as construction or building Street. However, this andesite turns out to have an abundant mineral feldspar composition. So that it can be used as a feldspar quarry industry.

Feldspar is generally used as an ingredient in the manufacture of ceramics and glass. The type of feldspar used in making ceramics is the type of orthoclast, microcline and albit or plagioclase acid (sodium feldspar). Feldspar in the form of alkaline plagioclase with high calcium levels cannot be used for ceramics. From the results of the chemical data in (Table 4.1 ), based on the chemical composition requirements of the feldspar for the ceramic and glass industry by PT. Semarang Mineral Development, 2015 sets the percentage standards:

1. Feldspar as flux for ceramics standards:
a) $\mathrm{K} 2 \mathrm{O}$ and $\mathrm{Na} 2 \mathrm{O}$ between $6-15 \%$
b) $\mathrm{Fe} 2 \mathrm{O} 3$ between $1.5-2.0 \%$

2. For glass-making mixtures standards:
a) $\mathrm{SiO} 2 \min 65 \%$
b) $\mathrm{Al} 2 \mathrm{O} 3 \min 17.5 \%$
c) $\mathrm{Fe} 2 \mathrm{O} 3<1 \%$

Other standards also set by the industry set by the Ministry of Industry are based on the Indonesian National Standard (SNI) with the following conditions:

1. Feldspar as flux for ceramics standards (SNI ISO 14703:2011):
a) $\mathrm{K}_{2} \mathrm{O}$ dan $\mathrm{Na}_{2} \mathrm{O}$ between $6,3-15,8 \%$
b) $\mathrm{Fe}_{2} \mathrm{O}_{3}$ between $1,8-2,1 \%$

2. For transparant glass-making mixtures standards (SNI ISO 12543-1:2011):
a) $\mathrm{SiO}_{2} \min 65,7 \%$
b) $\mathrm{Al}_{2} \mathrm{O}_{3}>18 \%$
c) $\mathrm{Fe}_{2} \mathrm{O}_{3}<0,8 \%$
d) $\mathrm{K}_{2} \mathrm{O}>10 \%$

3. For glass-making mixtures standards (SNI ISO 12543-1:2011):
a) $\mathrm{SiO}_{2}$ between $68-69,8 \%$ 

b) $\mathrm{Al}_{2} \mathrm{O}_{3}>17 \%$
c) $\mathrm{K}_{2} \mathrm{O}+\mathrm{Na}_{2} \mathrm{O}>11 \%$
d) $\mathrm{Fe}_{2} \mathrm{O}_{3} 0,1 \%-0,2 \%$

Based on the results of the specified standard values, the research location can be used as a raw material for making glass and as a flux in ceramic mixtures with the quality of mineral feldspar content is determined by the relatively high chemical oxide content of $\mathrm{K}_{2} \mathrm{O}$ and $\mathrm{Na}_{2} \mathrm{O}$ (above 6\%) and $\mathrm{Fe} 2 \mathrm{O} 3$ oxide between $1,5-2.0 \%$.

\subsection{Utilization of Silica in Andesites in the Manufacturing of Ceramics}

Silica is found in nature in the form of amorph hydrated, such as and butie $\left(\mathrm{CaB}_{2} \mathrm{Si}_{2} \mathrm{O}_{6}\right)$, olivine $\left((\mathrm{MgFe})_{2} \mathrm{SiO}_{4}\right.$, Albite $\left(\mathrm{NaAlSi}_{3} \mathrm{O}_{8}\right)$ and enstatite $\left(\mathrm{MgSiO}_{3}\right)$, when silica is heated continuously at temperatures above $650^{\circ} \mathrm{C}$, tends to increase crystallinity to form crystals namely cristobalite, tridymite and quartz (quartz).

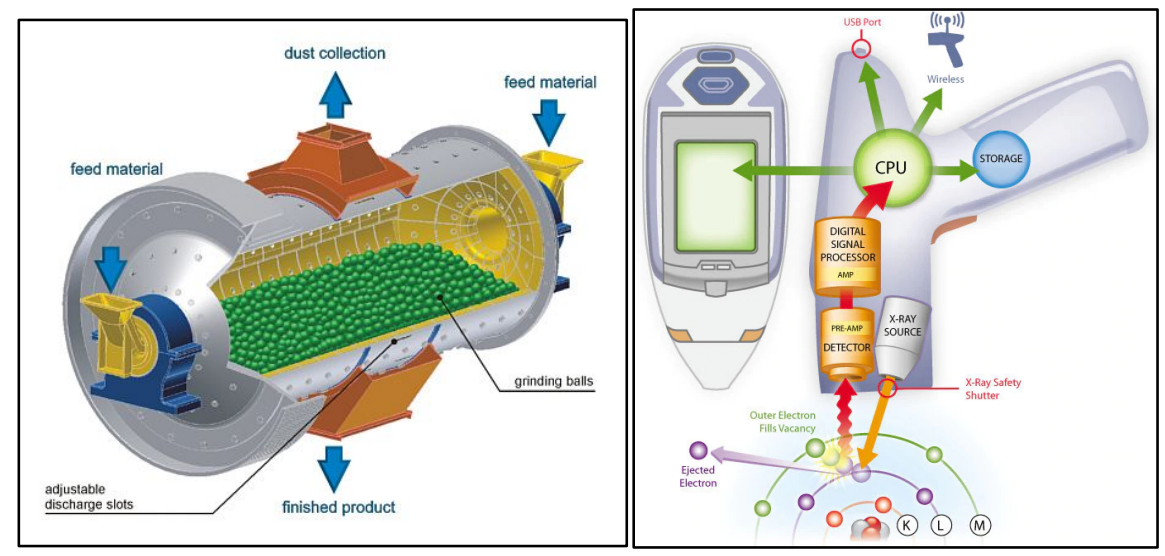

Fig. 9. The process is using a grinding machine (ball mill) and drying the materials with oven, and to test the ceramic sampel using XRF (X-Ray Fluoroscence)

The process of making ceramic samples is carried out in determining the composition of the test sample to be formed, which according to the purpose of this study, the composition of the test sample is varied, tuff $90 \%, \mathrm{Al}_{2} \mathrm{O}_{3} 5 \%$ and $\mathrm{MgO} 5 \%$. After weighing the composition, add water to each sample material that has been weighed as much as $25 \mathrm{~mL}$, then milling using a grinding machine (ball mill) (Fig. 9) with duration (time) for 4 hours aimed at making uniformity at the shape of the particle size or in other words make homogenization of the ceramic sample material, after the grinding process is complete, the next step is drying (Oven) which aims to eliminate the moisture content or release the water molecules contained in the ceramic sample material that is for \pm 12 hours with Temperature $100^{\circ} \mathrm{C}$, after the drying process is completed, the next process is the printing of the test sample material in which in this process the sample will be formed in the form of a pellet with a dry press method with a pressure of $80 \mathrm{~kg} / \mathrm{cm}^{2}$, and after the printing process on the sample the next step is the combustion process (sintering), where sintering is a combustion process that aims to bind to granules and reduce porosity at high temperatures and to obtain objects into compact and strong ceramics according to the desired specifications, $\mathrm{d}$ In this study the combustion temperature (sintering) was also carried out varying from temperatures of $600^{\circ} \mathrm{C}, 800^{\circ} \mathrm{C}, 1000^{\circ} \mathrm{C}, 1100^{\circ} \mathrm{C}, 1200^{\circ} \mathrm{C}$, this aims to determine the optimum combustion temperature in the ceramic test sample. 


\subsection{Utilization of Flour Andesites in the Manufacturing of Fertilizer}

Andesite rocks when crushed into fine flour, the first factor is 80 mesh $\left(\mathrm{H}_{1}\right), 40$ mesh $\left(\mathrm{H}_{2}\right)$, and 20 mesh $\left(\mathrm{H}_{3}\right)$. The second factor is the extractor, namely aquades $\left(\mathrm{P}_{0}\right)$, cow urine $\left(\mathrm{P}_{1}\right)$, pineapple water $\left(\mathrm{P}_{2}\right)$, and peat water $\left(\mathrm{P}_{3}\right)$. Andesite rocks are crushed and then filtered using a sieve according to the fineness treatment factor. Rock flour according to the level of fineness each weighed with a weight of $350 \mathrm{~g}$ then added with extractor as much as $700 \mathrm{~mL}$ in the form of cow urine and pineapple water that has been fermented for \pm 3 weeks, peat water and aquades.

The incubation of the two treatment factors was carried out for 4 weeks and stirred every day. After that, ultisol soil samples are added in a composite at a depth of 20-50 cm from the soil surface. Incubation resumed for 4 weeks. To maintain the condition of the soil to remain moist during incubation, watering is done using rain water. The analysis of soil properties was carried out after the incubation period ended including the determination of pH $\mathrm{H}_{2} \mathrm{O}$ electrometry method, P-available Bray II method, exchange bases ( $\mathrm{K}, \mathrm{Na}, \mathrm{Ca}, \mathrm{Mg}$ ), $\mathrm{CEC}$, and base saturation with the extract of $\mathrm{CH}_{3} \mathrm{COONH}_{4} 1 \mathrm{~N} \mathrm{pH} 7$.

The results of variance showed that on 4 weeks incubation ultisol an increase in soil reaction $\left(\mathrm{pH} \mathrm{H}_{2} \mathrm{O}\right)$ and soil K-exchange rate. Duncan's Multiple Range Test (DMRT) results of $5 \%$ level showed a marked improvement in both parameters with 80 mesh fineness. It is clearly known that the finer a material, the faster it dissolves and reacts in the soil [6]. The level of solubility will determine the quality of rocks used directly as ameliorant. Some rock solubility is also determined by its chemical reactivity. Finely ground rocks are potentially used as fertilizer $[7,8]$.

Ultisol exchange rate is classified as very high criteria influenced by the content of the type of rock-forming minerals (parent material) and climatic conditions during the weathering process. Andesite rock forming minerals which mainly consist of plagioclase feldspar and pyroxene (clinopyroxene and orthopyroxene) are generally minerals that have the highest potassium content.

The administration of andesite rock flour did not show a significant increase in $\mathrm{P}$ nutrient status and was still at a very low criterion due to the absence of apatite mineral content in andesite rocks where the mineral is a constituent mineral of phosphate rock. The same thing also happened to the $\mathrm{Ca}$ and $\mathrm{Na}$ nutrient status, where both nutrients are classified as low to very low. However, the presence or absence of $\mathrm{Na}$ content in the soil plays an important role in determining the characteristics of the soil in dry areas close to the coast. If $\mathrm{Na}$ is present in modest amounts in the soil, it is certain that plants that grow on the soil will be poisoned [9].

Although the fineness of andesite rock flour has no significant effect on Mgtukar ultisol, the $\mathrm{Mg}$ content in the soil is very high. This is influenced by the high content of $\mathrm{MgO}$ originating from andesite rocks. Based on the exchange base values $(\mathrm{K}, \mathrm{Na}, \mathrm{Ca}, \mathrm{Mg})$, it can be seen that the saturation level of the 4-week incubation ultisol base by giving andesite rock flour has not increased.

Based on the increase in the exchange rate and $\mathrm{Mg}$ exchange rates, it is certain that an increase in the saturation value of the soil base is also occurring. In addition [9] that there is a positive correlation between the percentage of base saturation and soil $\mathrm{pH}$. Giving cow urine can increase the criteria for soil properties to be very high due to the high $\mathrm{pH}$ of the soil due to the application. Base saturation is often considered as a indicator of soil fertility so that the soil is classified as medium fertility with a percent base saturation of between 50 and $80 \%$.

\section{CONCLUSION}


The existence of flow textures in petrography indicates that the ash material at that time was deposited on the andesites and flowed along. Andesite lava in Muria Mount is highly alkaline, potassium, and silica. The hardness of andesite and tuff tends to be more moderate than usual, so it is considered unsuitable for building foundations. Andesite and tuff in the study area are currently being mined to be used as raw material for glass makers because of their very high silica content. The hardness of andesite and tuff tends to be more moderate than usual, so it is considered unsuitable for building foundations. Andesite and tuff in the study area are currently being mined to be used as raw material for glass makers because of their very high silica content. In the industrial sector, the andesite is used as feldspar minerals for flux glass, and ceramic raw materials with the standard reference of PT Semarang Mineral Pembangunan and SNI ISO 14703: 2011 No 1147-1984 and SNI ISO 12543: 2011. The lithology tuff can be utilized in the manufacturing of ceramics due to high silica and felspar content. The lithology andesite can be utilized as the andesite rocks flour in the manufacturing of fertilizer due to high natrium, potassium, and magnesium content.

\section{References}

1. R.W. Van Bemmelen, The Geology of Indonesia, 1A, (Netherland, The Hague Martinus Nijhoff, 1949)

2. Suwarti and Wikarno, Peta Geol. Lbr. Kudus (Bandung, Pusat Penelitian dan Pengembangan Geologi, 1992)

3. R. B. Travis, Class. of Rocks, 4 (Colorado School of Mines, 1955)

4. A. L. Streckeisen, Class. and Nomencl. of Ign. Rocks, 107, 144-240 (Neues Jahrbuch fur Mineralogie, Abhandlungen, 1967)

5. F.J. Pettijohn, Sed. Rocks. (New York-Evanston-San Fransisco-London, Harper \& Row Publishers 1975)

6. H.O. Buckman, and N.C. Brady, Ilm. Tnh. (Bhratara Karya Aksara, Jakarta, 1982)

7. W. Hartatik, Fos. A. Sbr. Pupuk P. M. (Balai Penelitian Tanah, Bohor, 2011)

8. J. Priyono, P. Bat. Sil. Sbg. Pupuk Rmh. Ling. (Universitas Mataram, 2005)

9. K.H. Tan, Dsr-dsr Kim. Tnh. (Gadjah Mada University Press, Yogyakarta, 1998) 